\title{
RECOVERY OF THORIUM FROM A WYOMING ORE
}

By S. R. Borrowman and J. B. Rosenbaum

* * * * * * * * * report of investigations 5917

UNITED STATES DEPARTMENT OF THE INTERIOR

Stewart L. Udall, Secretary

BUREAU OF MINES

Marling J. Ankeny, Director 


\section{DISCLAIMER}

This report was prepared as an account of work sponsored by an agency of the United States Government. Neither the United States Government nor any agency Thereof, nor any of their employees, makes any warranty, express or implied, or assumes any legal liability or responsibility for the accuracy, completeness, or usefulness of any information, apparatus, product, or process disclosed, or represents that its use would not infringe privately owned rights. Reference herein to any specific commercial product, process, or service by trade name, trademark, manufacturer, or otherwise does not necessarily constitute or imply its endorsement, recommendation, or favoring by the United States Government or any agency thereof. The views and opinions of authors expressed herein do not necessarily state or reflect those of the United States Government or any agency thereof. 


\section{DISCLAIMER}

Portions of this document may be illegible in electronic image products. Images are produced from the best available original document. 

Summary and introduction.................... 1

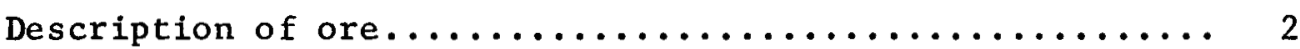

Physical beneficiation........................ 2

Leaching of monazite concentrate................ 3

Alkaline decomposition of monazite........... 4

Acid decomposition of monazite.............. 4

Liquid-solids separation................. 4

Recovery of thorium from Bald Mountain leach solutions.... 4

Conceptual flowsheet and materials balance.......... 6 .

Tests for recovering rare-earth byproducts........... 6

Conclusions ............................... 8

Fig.

\section{ILLUSTRATION}

1. Postulated flowsheet and materials balance for processing Bald Mountain monazite concentrate......

TABLE

1. Petrographic estimation of size of monazite grains in

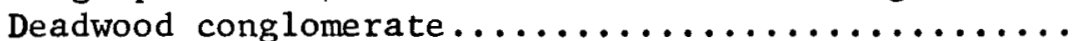




\section{RECOVERY OF THORIUM FROM A WYOMING ORE'}

S. R. Borrowman ${ }^{2}$ and J. B. Rosenbaum ${ }^{3}$

\section{SUMMARY AND INTRODUCTION}

Physical beneficiation, leaching, and solvent extraction investigations were made to recover a high-grade thorium oxide product from Bald Mountain, Wyo., conglomerate. The monazite in the Bald Mountain deposit contains 8.8 percent $\mathrm{ThO}_{2}$ and, therefore, is higher in thorium content than the usual domestic or foreign monazite. A sample of composited drill cuttings for the study contained 4.3 pounds of monazite per ton of ore.

The work showed that the monazite, although unusually fine grained and friable, could be concentrated by tabling and magnetic treatment to yield a product assaying 5.65 percent $\mathrm{ThO}_{2}$ with a recovery of 61 percent of the thorium. Subsequent decomposition of the concentrate by treatment with sulfuric acid and solvent extraction of the resultant solution with a primary aliphatic amine yielded a thorium oxide product of 99-percent grade.

Reconnaissance tests indicated that the thorium tailing solution was amenable to further processing for recovery of a bulk rare-earth oxide or a discrete cerium fraction.

Among the world's principal sources of thorium are the monazite sands of India, Brazil, Africa, Australia, and Malaya. Dow Chemical Co. currently recovers thorium from uranium tailings solution in the Blind River-Elliot Lake district, Canada. 4 Thorianite and thorite ores have yielded small quantities of thorium in the past, but only recently sufficient quantities have been found to warrant their consideration as major potential resources of thorium. A description of domestic thorite deposits, together with a detailed account

${ }^{1}$ Work on manuscript completed January 1961.

${ }^{2}$ Chemist, Salt Lake City Metallurgy Research Center, Bureau of Mines, Salt Lake City, Utah.

${ }_{3}^{3}$ Supervising metallurgist, Salt Lake City Metallurgy Research Center, Bureau of Mines, Salt Lake City, Utah.

4 Journal of Metals, Thorfum Produced in Canada: Vo1. 11, No. 9, September 1959, p. 557. 
of metallurgical research to develop recovery procedures, has been presented in a report. ${ }^{5}$

Monazite is found in the United States in North and South Carolina, Florida, California, Idaho, and Wyoming. However, the thorium content of monazite from a deposit at Bald Mountain, Wyo., was higher than in other domestic monazites. Hence, as an extension of the study on recovery of thorium from other domestic ores, research was conducted to determine the amenability of Bald Mountain ore to physical concentration and to the sulfuric acid leach-amine solvent extraction process developed for treatment of thorite ores.

\section{DESCRIPTION OF ORE}

The Deadwood conglomerate occurring in the vicinity of Bald Mountain contains an estimated 20 million tons of material averaging about 2.5 pounds of monazite per ton. A high-grade stratum developed during the drilling program of the Bureau of Mines contained 675,000 tons of conglomerate averaging 13.2. pounds of monazite per ton. The average $\mathrm{ThO}_{2}$ content of the monazite was 8.8 percent.

A composite sample of 1,400 pounds of drill cores available for the metallurgical investigation contained 0.019 percent $\mathrm{ThO}_{2}$, equivalent to 4.3 pounds of monazite per ton. The sample thus contained a disproportionate amount of material from the high-grade stratum. Microscopic examination showed that the principal constituents of the composite sample were quartz and feldspars; minor components were garnet, hematite, limonite, magnetite, ilmenite, zircon, and monazite.

\section{PHYSICAL BENEFICIATION}

Previous experience in concentration of Bald Mountain ore, developed in supporting the field reconnaissance, pointed to a combination of tabling and magnetic separation as the preferred beneficiation procedure to yield a monazite concentrate suitable for studies on leaching and solvent extraction.

A concentrate containing a minimum of 5 percent $\mathrm{ThO}_{2}$ appeared to be a reasonable target for the beneficiation work.

As shown in table 1, monazite grains, in the Deadwood conglomerate, are unusually fine in size.

The monazite grains in the crude ore were extensively fractured and were subject to further size degradation when the ore was crushed to 20-mesh for concentration by tabling. Despite the extreme fineness of the monazite, reasonably satisfactory results were attained by physical beneficiation.

${ }^{5}$ Borrowman, S. R., and Rosenbaum, J. B., Recovery of Thorium From Ores in Colorado, Idaho, and Montana: Bureau of Mines Rept. of Investigations $5916,1962,35 \mathrm{pp}$. 
TABLE 1. - Petrographic estimation of size of monazite grains in Deadwood conglomerate

\begin{tabular}{|c|c|}
\hline Screen size, mesh & $\begin{array}{c}\text { Monazite grains, } \\
\text { percent }\end{array}$ \\
\hline \multirow{4}{*}{ 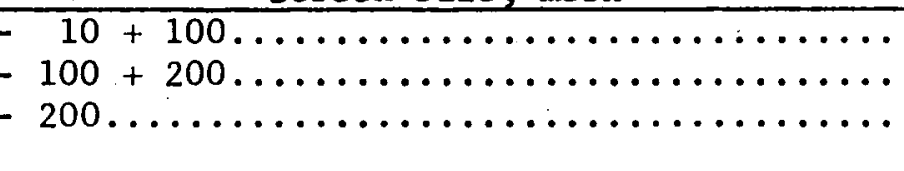 } & 52 \\
\hline & 17 \\
\hline & 31 \\
\hline & 100 \\
\hline
\end{tabular}

The concentrate produced by tabling, which constituted on 1 y 0.75 percent of the weight of the table feed, contained 69 percent of the thorium and assayed 1.72 percent $\mathrm{ThO}_{2}$. A middling product that assayed 0.26 percent $\mathrm{ThO}_{2}$ and contained 6 percent of the thorium was discarded along with table tails. This middling probably could be recycled in plant practice to improve the recovery.

The table concentrate was dried and treated on a high intensity magnetic separator to yield a nonmagnetic fraction that represented 0.21 percent of the original ore, assayed 5.65 percent $\mathrm{ThO}_{2}$, and contained 61 percent of the thorium in the ore. An overall 300-to- 1 thorium enrichment ratio was effected by physical beneficiation. The final concentrate also contained, in percent, $40.4 \mathrm{RE}_{2} \mathrm{O}_{3}, 7.0 \mathrm{ZrO}_{2}, 3.6 \mathrm{TiO}_{2}, 5.3 \mathrm{Fe}_{2} \mathrm{O}_{3}, 23.6 \mathrm{PO}_{4}, 10.4 \mathrm{SiO}_{2}, 1.2 \mathrm{Al}_{2} \mathrm{O}_{3}, 1.0$ $\mathrm{CO}_{2}$, and $1.0 \mathrm{CaO}$ plus $\mathrm{MgO}$.

\section{LEACHING OF MONAZITE CONCENTRATE}

The standard methods of decomposing monazite sand are treatment with hot concentrated alkali or hot concentrated sulfuric acid.' Alkaline decomposition does not dissolve the thorium but. converts it into an oxide that is readily soluble in dilute sulfuric acid. Details of these respective procedures are contained in reports from Battelle Memorial Institute ${ }^{6}$ and Iowa State College. ${ }^{7} 8$

Reconnaissance tests indicated that either the alkaline or acid procedures resulted in rendering about 97 percent of the thorium soluble. However, the alkaline decomposition and subsequent acid extraction resulted in solutions that were grossly contaminated with zirconium and titanium. Because both zirconium and titanium interfere with solvent extraction recovery of thorium, the acid procedure that rendered lesser quantities of these elements soluble was adopted for routine preparation of the thorium leach solution.

${ }^{6}$ Calkins, C. D., and Others, Recovery of Thorium From Monazite Sands: Battelle Memorial Inst., BMI-234, vo1. I, and BMI-234A, vol. II, September 1950, $221 \mathrm{pp}$.

${ }^{7}$ Bleckwedil, T. W., Decomposition of Monazite: USAEC Rept. ISC-66, Iowa State College, 1949,26 pp.

${ }^{8}$ Shaw, K. G., and Others, A Process for Separating Thorium Compounds From Monazite Sands: USAEC Rept. ISC-407, Iowa State College, 1954, 109 pp. 


\section{Alkaline Decomposition of Monazite}

Both caustic digestion and soda-ash roasting were examined as a means of decomposing the monazite concentrate. Either method was effective. The caustic leach liquor from the digestion and the leach solution from water extraction of the soda-ash calcine both contained essentially all the phosphate present in the concentrate. A subsequent dilute acid leach of either of the alkaline residues dissolved 97 percent of the thorium, 66 percent of the rare-earth elements, and about 40 percent of the zirconium and titanium.

\section{Acid Decomposition of Monazite}

The following procedure proved effective and convenient for acid decomposition of Bald Mountain monazite concentrate. The concentrate was dry ground to pass 100 -mesh, then added to 1.5 times its weight of 96 percent $\mathrm{H}_{2} \mathrm{SO}_{4}$ heated to $200^{\circ} \mathrm{C}$. in an open vessel. The temperature rose to $245^{\circ} \mathrm{C}$., and the mass solidified after about 2 hours. Subsequently, the reacted mass was agitated for 1 hour with 5 parts by weight of water per part of original concentrate, then filtered and washed with water acidified to a $\mathrm{pH}$ of 1 . Wash solution was combined with the filtrate to yield 10 parts of pregnant solution that assayed 5.46 grams per liter of $\mathrm{ThO}_{2}$ per part of ore and contained 97 percent of the thorium.

The dried leach residue remaining represented 30 percent of the weight of the feed and contained 0.60 percent $\mathrm{ThO}_{2}$ and 4.4 percent $\mathrm{RE}_{2} \mathrm{O}_{3}$.

\section{Liquid-Solids Separation}

Because 70 percent of the weight of the concentrate was rendered soluble by the acid cure, subsequent dilution of the reactant mass with 5 parts of water, as previously described, yielded a slurry containing only 6 percent solids. The slurry was effectively flocculated with 0.2 pound of Dow Chemical Co. Separan 9 per ton of concentrate and filtered and washed on a Buchner filter. The filter cake contained 70 percent solids. Quantitative filtration data were not obtained, but no unusual handling problems were encountered.

\section{RECOVERY OF THORIUM FROM BALD MOUNTAIN LEACH SOLUTIONS}

Investigators at Dow Chemical Co., Kennecott Copper Co., and the Oak Ridge National Laboratory are among those who have studied application of solvent extraction to recovery of thorium from sulfuric acid solutions. Both Dow and Kennecott ${ }^{10} 11$ used alkyl phosphates in their work. The Oak Ridge

\footnotetext{
${ }^{9}$ Reference to specific proprietary reagent is made to facilitate understanding and does not imply endorsement of such brands by the Bureau of Mines.

${ }^{10}$ Christensen, C. C., and Prater, J. D., Liquid-Liquid Extraction Process for the Recovery of High-Purity Thorium Oxide: U.S. Patent 2,945,742, July $19,1960$.

${ }^{11}$ Work cited in footnote 4.
} 
National Laboratory ${ }^{12}$ proposed an amine extraction system for thorium from monazite solutions somewhat analogous to that developed by the Bureau for thorite leach liquor. ${ }^{13}$ However, the monazite leach solution prepared from Bald Mountain concentrate was different from the solution used at Oak Ridge, and the solvent extraction procedures differed also in several respects. For these reasons bench-scale studies on Bald Mountain monazite leach liquor using the Bureau's thorite leach liquor process appeared warranted.

The leach solution obtained by acid decomposition of Bald.Mountain monazite concentrate had an $0.1 \mathrm{pH}$ and contained, in grams per liter, 5.46 $\mathrm{ThO}_{2}$, $39.1 \mathrm{RE}_{2} \mathrm{O}_{3}, 1.5 \mathrm{Fe}, 0.3 \mathrm{TiO}_{2}, 0.01 \mathrm{ZrO}_{2}, 19.6 \mathrm{PO}_{4}$, and $146 \mathrm{SO}_{4}$. It differed from thorite leach liquor, particularly in having a much lower iron assay and a much higher rare-earth and phosphate content.

A miniature, multiple-stage, compartmented contactor was used for the countercurrent solvent extraction tests. The extractant was a 10-percent solution of an aliphatic primary amine (Rohm and Haas Primene JM- $T$ ) in kerosine with 5 percent primary decyl alcohol (PDA) added to improve phase disengagement. Thorium was stripped from the loaded organic by means of a 1.5 normal sodium chloride-0.5 normal hydrochloric acid solution.

Operation with four extraction and three stripping stages at feed liquor, organic, and strip solution flow ratios of 10:7.5:4 yielded raffinate containing 0.01 gram per liter of $\mathrm{ThO}_{2}$ and loaded organic and strip solution containing 7.3 and 13.6 grams per liter of $\mathrm{ThO}_{2}$, respectively. Before being stripped, the loaded organic was scrubbed in two stages with 0.2 molar sulfuric acid solution at an organic-to-aqueous ratio of 7.5 to 2 for removal of contaminating rare-earth oxides.

Titanium was not extracted under the conditions used. Zirconium probably was extracted, but serious contamination did not result because of the extremely low zirconium content in the feed solution. If much zirconium had been present, a preliminary extraction of the zirconium by a secondary amine probably would have been necessary.

The chloride strip solution contained sulfate ion, which was removed along with the thorium from the loaded organic. Neutralization of the loaded strip liquor to a $\mathrm{pH}$ of 5 by addition of soda ash thus precipitated the thorium as a hydrous sodium thorium sulfate. After filtration, the precipitate was digested with caustic for formation of hydrous thorium oxide, and this in turn was ignited at $850^{\circ} \mathrm{C}$. to yield thorium oxide of 99-percent grade. Principal contaminants comprising the remaining 1 percent were rare-earth oxide, sulfate, phosphate, alumina, and silica.

${ }^{12}$ Crouse, D. J., and Brown, K. B., Recovery of Thorium, Uranium, and Rare Earths From Monazite Sulfate Liquors by the Amine Extraction (Amex)

Process: Oak Ridge National Lab., ORNL-2720, August 1959, 63 pp.

${ }^{13}$ Work cited in footnote 5 . 


\section{CONCEPTUAL FLOWSHEET AND MATERIALS BALANCE}

A conceptual flowsheet and materials balance projected from the laboratory findings is given in figure 1 . A ton of monazite concentrate, assaying 5.65 percent $\mathrm{ThO}_{2}$, is shown to yield 110 pounds of 99 percent thoria containing 108.8 pounds of thorium oxide. Reagent requirements per ton of concentrate are shown as 3,100 pounds of sulfuric acid, 700 pounds of salt, 150 pounds of hydrochloric acid, 200 pounds of soda ash, and 30 pounds of caustic soda. In addition, about 1 gallon of organic solution would be lost per ton of concentrate.

\section{TESTS FOR RECOVERING RARE-EARTH BYPRODUCTS}

The recovery from the thorium raffinate of a bulk rare-earth product and of a discrete cerium fraction was examined briefly.

Addition of 60 grams per liter of sodium sulfate to the raffinate precipi-

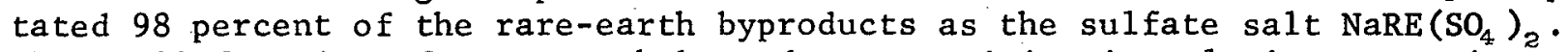
The small fraction of rare-earth byproducts remaining in solution was principally of the yttrium group. Treatment of the rare-earth sulfate with caustic soda yielded a rare-earth hydroxide precipitate in accordance with the following reaction:

$$
\mathrm{NaRE}\left(\mathrm{SO}_{4}\right)_{2}+3 \mathrm{NaOH} \longrightarrow \mathrm{RE}(\mathrm{OH})_{3}+2 \mathrm{Na}_{2} \mathrm{SO}_{4}
$$

The bulk rare-earth hydroxide was dried at $140^{\circ} \mathrm{C}$. and then dissolved in cold 6.7 normal sulfuric acid to obtain a solution in which the cerium was largely in the tetravalent form. Subsequently, the solution was adjusted with cold 0.5 molar sulfuric acid to yield a feed liquor of $0.1 \mathrm{pH}$ that contained 19 grams per liter total of $\mathrm{RE}_{2} \mathrm{O}_{3}, 7.4$ grams per liter of $\mathrm{Ce}^{+4}$, and 0.3 gram per liter of $\mathrm{Ce}^{+3}$, for cerium solvent extraction tests.

Laboratory rotary column contactors were used for extraction, stripping, and scrubbing with 10 percent $\mathrm{JM}-\mathrm{T}$ and 5 percent PDA in kerosine, 1.5 normal $\mathrm{NaCl}$ and 0.5 normal $\mathrm{HCl}$, and 1 molar $\mathrm{Na}_{2} \mathrm{SO}_{4}$ and 0.1 molar $\mathrm{H}_{2} \mathrm{SO}_{4}$, respectively. The sulfate scrub was necessary to remove chloride ion from the recycled organic and thereby preclude reduction of the ceric ion in the extraction step.

Cerium in the quadrivalent form was effectively and selectively extracted at flow rates, in milliliters per minute, of 0.9 aqueous feed, 1.8 organic, 1.5 chloride strip, and 2.0 sulfate scrub. The raffinate contained 0.3 gram per liter of $\mathrm{Ce}^{+3}$ and $\mathrm{nil} \mathrm{Ce} \mathrm{Ce}^{+4}$, and the strip liquor contained 4.4 grams per liter of $\mathrm{Ce}^{t^{4}}$. A reaction between ceric ion and a component of the primary amine was evident initially and resulted in a temporary level of 0.4 gram per liter cerous ion in the raffinate. However, after three organic cycles, reduction of ceric ion by the organic ceased.

A cerium oxide product was prepared from the loaded chloride solution by precipitating sodium ceric sulfate at a $\mathrm{pH}$ of 5 , converting the sulfate to ceric hydroxide by reaction with caustic soda, and igniting the hydroxide at 
LEACH AND LIQUID-SOLIDS SEPARATION

SOLVENT EXTRACTION

Grind minus $100-m e s h$
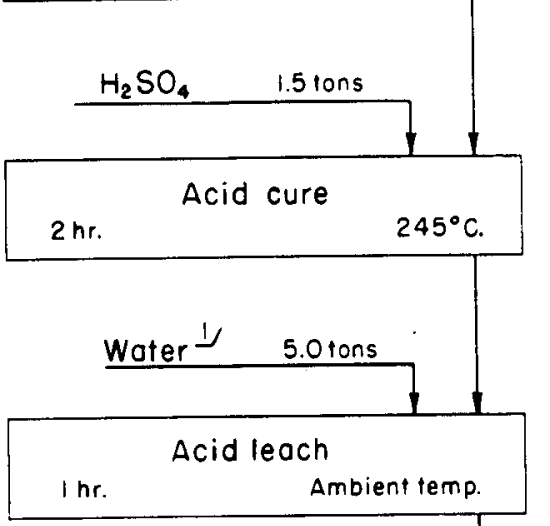

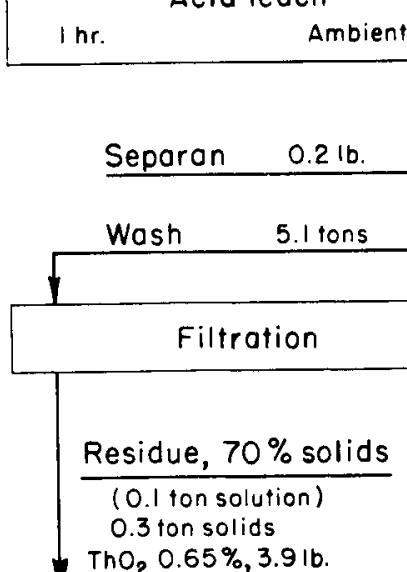

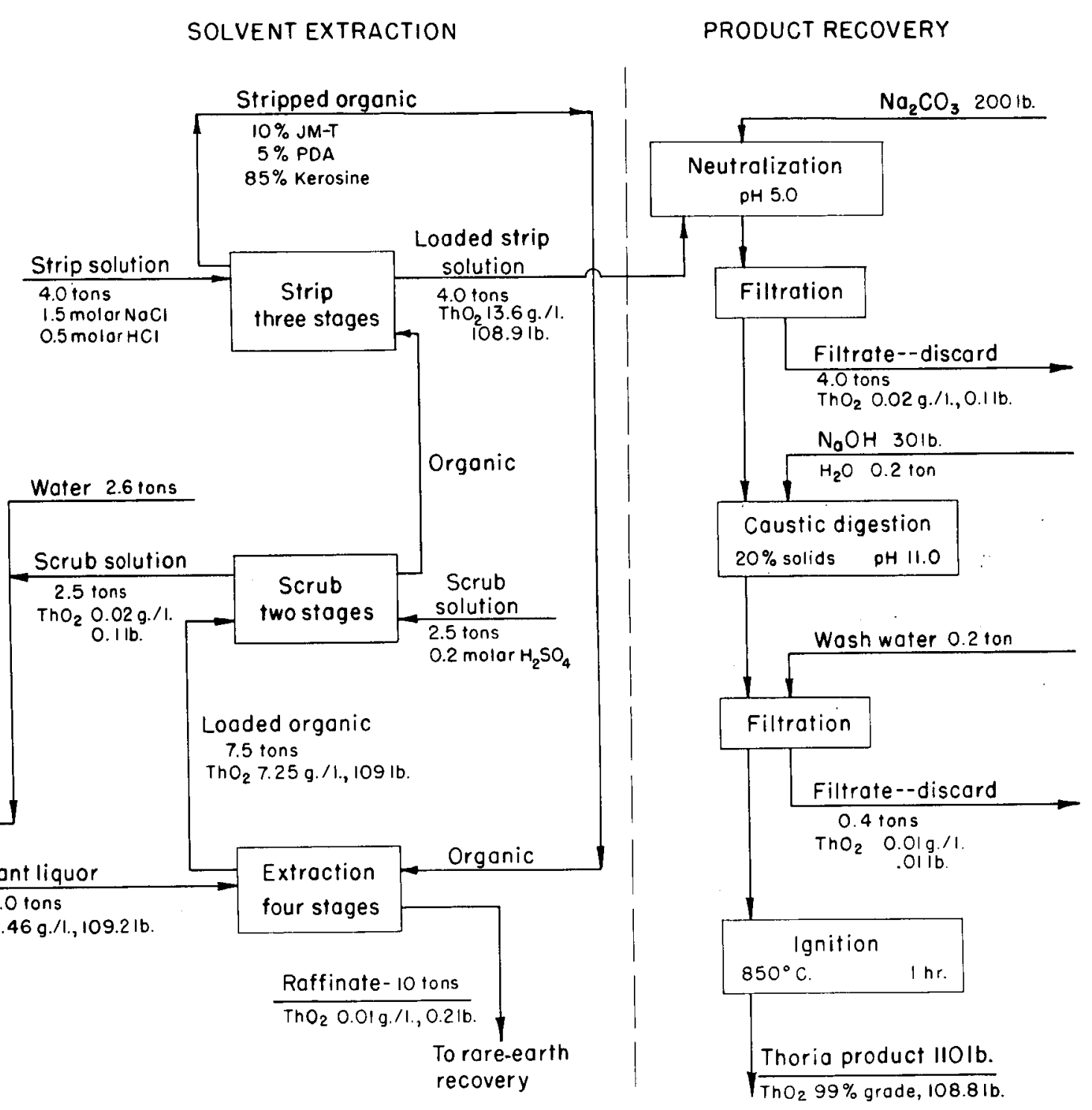

1) Solution quontities in volume tons of 240 gallons.

FIGURE 1. - Postulated Flowsheet and Materials Balance for Processing Bald Mountain Monazite Concentrate. 
$1,000^{\circ} \mathrm{C}$. The product contained 99 percent $\mathrm{CeO}_{2}$. The remaining 1 percent was comprised principally of lanthanum and neodymium oxides.

\section{CONCLUSIONS}

The investigation indicates that monazite concentrate prepared from Bald Mountain conglomerate can be decomposed by the conventional sulfuric acid cure treatment and that the resultant acid leach liquor can be processed by primary amine solvent extraction to yield a 99-percent thorium oxide product.

The thorium raffinate appears amenable to further processing for recovery of a bulk rare-earth oxide product or of a separate cerium fraction that assays 99 percent $\mathrm{CeO}_{2}$. 